\title{
With \#IchBinHanna, German academia protests against a law that forces researchers out
}

To the Editor - In early summer 2021, the hashtag \#IchBinHanna ("I am Hanna”) has been trending on Twitter. It represents the peak of protests against a German law, the Wissenschaftszeitvertragsgesetz (WissZeitVG; academic fixed-term contract act $)^{1}$, and traces back to a (now deleted) video by the German Federal Ministry of Education and Research (https://go.nature. $\mathrm{com} / 3 \mathrm{z} 3 \mathrm{BCm} 8)$. In this video, a fictional character named Hanna was used to explain the ostensible advantages and necessity of the law. It was stated that, without the law, Hanna would clog the system, and that the constant turnover of staff was a driving force for innovation. Under the hashtag, thousands of researchers from various domains have joined the protest on Twitter - and received broad attention in the media (https://ichbinhanna.wordpress.com) and even federal politics (https://go.nature. com/36EXUyo) (Fig. 1). The initiators of the hashtag, who are among the authors of this article, argue that the WissZeitVG fails to achieve the claimed advantages, is toxic for academia and is detrimental to society (https://go.nature.com/3xLcWyi).

First, the law impedes German academia from flourishing and represents a systematic waste of intellectual resources. Like in other countries, most researchers are on a large number of brief fixed-term contracts throughout their career. In Germany, however (note that Austria adopted a similar law in May 20212), the WissZeitVG enacts that researchers can only be employed on fixed-term contracts for six years before and six after their PhD. Thus, with few exceptions, after 12 years, researchers who have not been offered a professorship or one of the few other tenured positions are forced to leave German academia - for good. This inevitable loss of highly qualified personnel seriously darkens the prospects of German academia.

Second, the WissZeitVG represents a waste of public money and helps to manifest precarious working conditions,

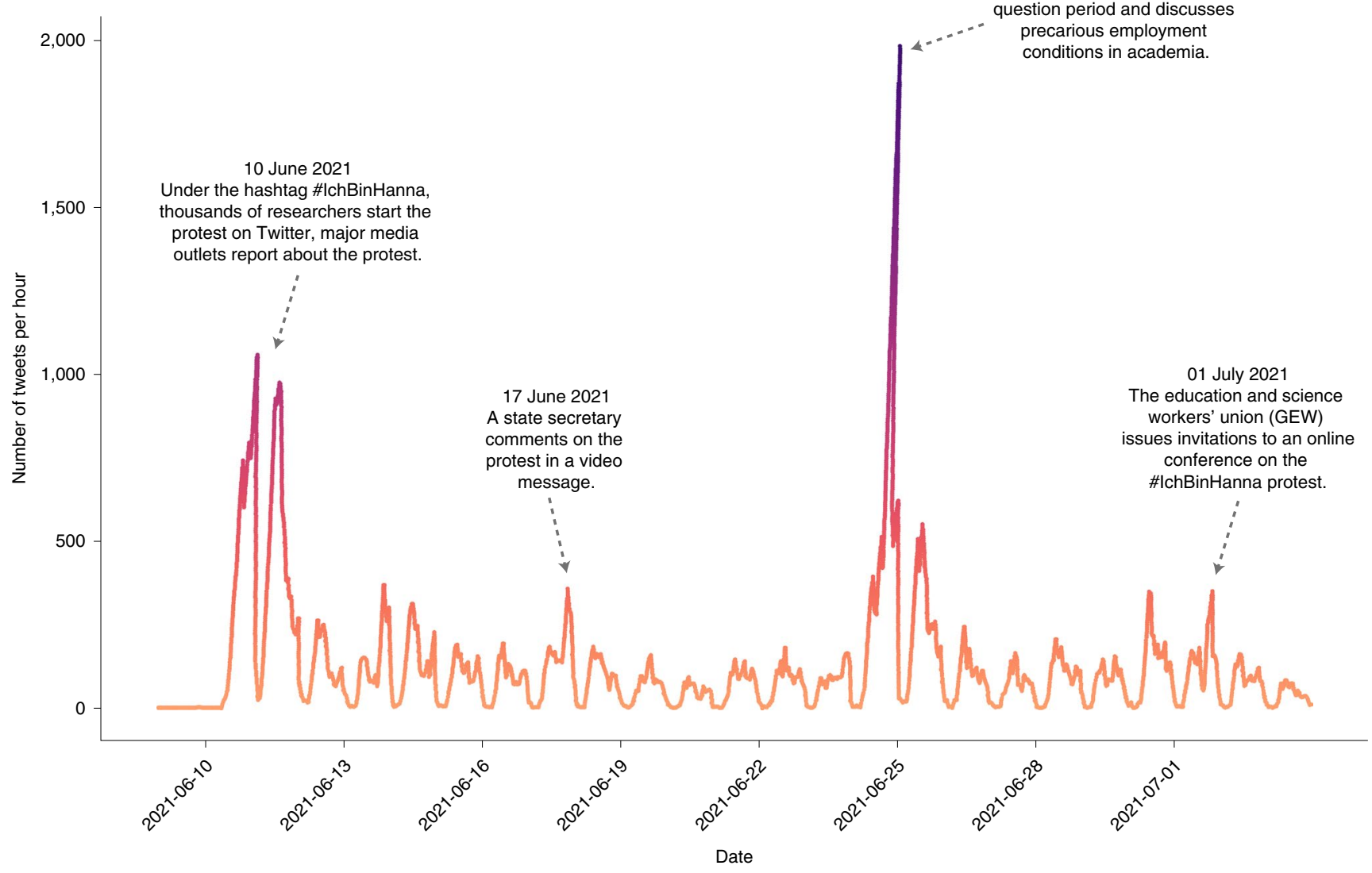

Fig. 1 | Development of the protest and relevant political reactions. The line plot shows the number of tweets per hour with the \#IchBinHanna hashtag and relevant variants between 8 June and 3 July 2021. In total, there were 75,762 tweets related to the protest in this period. Data were supplied by the \#lchBinHanna Research Collective ${ }^{5}$ and extracted from the provided figure (https://lasersteff.github.io/Hanna_time/) using the Web Plot Digitizer (https://apps.automeris.io/wpd/; version 4.4). 
with detrimental consequences for society, research and individual researchers. Specifically, the WissZeitVG often delays the definite decision on whether someone can stay in academia until researchers are in their forties. It does so by continuously fuelling young researchers' hope for a professorship with the six-year limit hanging above their brilliant minds like the sword of Damocles. Thereby, the law also makes researchers accept highly problematic working conditions ${ }^{3,4}$. When time is up, the unlucky Hannas are forced to leave the system at an age when they will have difficulties finding work outside academia. With them, much of the public money invested leaves the system too. Beyond this, the chains of short-term contracts result in abandoned projects when a researcher's contract ends before completion, which hinders advance and innovation; not to mention long-term research projects, which cannot be approached at all with short-term contracts. At an individual level, the hope for a professorship hampers researchers' life planning and forces them into a 'nomadic life'; many postpone starting a family while longing for more security - and may still be forced to eventually leave academia. Those who lack financial backing or familial support, or simply decide they cannot afford the precarious conditions, are likely to be deterred from pursuing an academic career, with consequences for diversity.

In summary, Germany builds expertise with public money only to lose it when researchers reach their sell-by date and turn their back on (German) academia. In the meantime, other countries have discovered that it is worth headhunting them. If German politics does not react, international competitive disadvantages are inevitable.

\section{Amrei Bahr (D) 1凶, Christine Blume (D) 2,3, Kristin Eichhorn (iD ${ }^{4}$ and Sebastian Kubon (iD) 5 ${ }^{1}$ Department of Philosophy, Heinrich Heine University, Duesseldorf, Germany. ${ }^{2}$ Centre for Chronobiology, Psychiatric Hospital of the University of Basel, Basel, Switzerland. ${ }^{3}$ Transfaculty Research Platform Molecular and Cognitive Neurosciences, University of Basel, Basel, Switzerland. ${ }^{4}$ Institute} for German Language and Comparative Literature,
Paderborn University, Paderborn, Germany. ${ }^{5}$ Department of History, University of Hamburg, Hamburg, Germany.

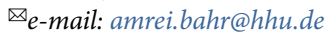

Published online: 2 August 2021

https://doi.org/10.1038/s41562-021-01178-6

\section{References}

1. Gesetz über befristete Arbeitsverträge in der Wissenschaft (Wissenschaftszeitvertragsgesetz - WissZeitVG). Bundesamt für Justiz https://go.nature.com/3rcE8Ua (2020).

2. 93. Bundesgesetz, mit dem das Universitätsgesetz 2002, das Hochschul-Qualitätssicherungsgesetz, das Hochschulgesetz 2005, das Fachhochschulgesetz und das Privathochschulgesetz geändert werden. Bundeskanzleramt der Republik Österreich https:// go.nature.com/3iilWUb (2021).

3. Hobler, D. \& Reuyss, S. DGB Hochschulreport: Arbeits- und Beschäftigungsbedingungen an Hochschulen in Deutschland (Deutscher Gewerkschaftsbund, 2020).

4. Confederation of German Trade Unions, Bolenius, S. \& Hannack, E. DGB Report on Higher Education Institutions: Selected Findings. Temporary Contracts and Overtime Are the Norm in Academia (DGB, 2020).

5. Analysis of Tweets for the \#IchBinHannah Campaign (GitHub repository, 2021); https://doi.org/10.5281/ zenodo. 5068748

Competing interests

The authors declare no competing interests. 